\title{
M-Learning: An Integrative Approach to Increase Student Engagement ${ }^{1}$
}

\section{(El aprendizaje móvil: enfoque integrador para aumentar la participación de los estudiantes)}

\author{
Vivian Vargas Barquero² \\ Universidad Nacional, Costa Rica \\ Natin Guzmán Arce ${ }^{3}$ \\ Universidad Nacional, Costa Rica
}

\begin{abstract}
M-learning utilizes handheld electronic devices as didactic tools for facilitating learning and teaching within real-time access in the language classroom. Current studies on m-learning suggest that the incorporation of electronic devices can lead to greater student engagement and better performance. Using a questionnaire, 22 professors from the major Bachelor's in the Teaching of English as a Foreign Language from the Universidad Nacional (Costa Rica) were surveyed about how mobile devices are being implemented in the language classroom.

\section{RESUMEN}

El aprendizaje móvil utiliza dispositivos electrónicos como procedimiento didáctico para el aprendizaje en la clase en tiempo real. Estudios recientes sobre aprendizaje móvil sostienen que el uso de estos dispositivos mejora la participación y el rendimiento académico del estudiante. Mediante un cuestionario se consultó a veintidós profesores del Bachillerato en la Enseñanza del Inglés en la Escuela de Literatura y Ciencias del Lenguaje
\end{abstract}

1 Recibido: 25 de febrero de 2019; aceptado: 20 de agosto de 2019.

2 Escuela de Literatura y Ciencias del Lenguaje. Correo electrónico: vivian.vargas.barquero@una.ac.cr

3 Escuela de Literatura y Ciencias del Lenguaje. Correo electrónico: natin.guzman.arce@una.ac.cr

LETRAS 67 (2020), ISSN 1409-424X; EISSN 2215-4094

Doi: http://dx.doi.org/10.15359/rl.1-67.7

www.revistas.una.ac.cr/index.php/letras 
(ELCL) de la Universidad Nacional de Costa Rica, para recabar sobre el modo en que los dispositivos móviles se usan el clase.

Keywords: M-learning, mobile teaching devices, language learning Palabras clave: aprendizaje móvil, dispositivos didácticos, aprendizaje de lenguas

\section{Introduction}

Technological devices available on the market have changed people's way of living and working; indeed, today's world offers a wide range of electronic tools. According to the Office of Telecommunications (Superintendencia de Telecomunicaciones, SUTEL), in Costa Rica there are about 8.8 million active users of cellphones, of whom 4.8 million have access to Internet on their phones to carry out daily activities. ${ }^{4}$ Many companies worldwide have spread their client portfolios through technological advances, app development and website trade, combining the physical world and the virtual one. In particular, giant companies (such as Amazon or Apple) or even entertainment firms (such as Netflix) use their technological platforms to reach larger market targets. This leads to new possibilities in the field of education as well. Technology has influenced educational systems at all levels: primary, secondary and higher education. Because access to online information is immediate, educators should be encouraged to use technology more in daily teaching. Advertisements of newly released apps to learn faster, easier, and more independently appear constantly on users' devices. Considering that learning a foreign language is part of educational curricula, the market offers language learning apps such as Improve English, Duolingo or Basuu that aim to assist students in the process of learning a foreign or a second language. Along with these apps,

4 Carlos Cordero, "Sigue aumento de uso de Internet móvil en Costa Rica, pero cae la velocidad promedio de 4G," El financiero, $19 \mathrm{Feb} .2018,<\mathrm{https}$ //www.elfinancierocr.com/tecnologia/sigueaumento-de-uso-de-internet-movil-en-costa/6CDA3KNM6ND3BOC4BARGYKSGV4/story/ https://www.elfinancierocr.com>. 
user-friendly software and digital resources are accessible to learners and instructors. This has led to the development of a novel teaching approach which incorporates technological devices as a means of instruction known as mobile learning (m-learning).

M-learning is a type of teaching/learning approach which is being integrated in many disciplines. Regardless of whether the impact is positive or negative, technological advances are used broadly, including the acquisition of a second language. Smart phones, tablets, E-book readers, portable media players, and recently smart watches are now the most extensively handled mobile devices. They support people's lifestyles by storing data, entertaining users, accessing information in real time, contacting friends and family, recording messages, reading news and books, listening to music, and watching movies, to name a few. Likewise, the widely available mobile technologies open up new possibilities regarding language education to assist teaching and learning by using personal electronic devices as a classroom resource to exploit the familiarity, portability and ubiquity of mobile devices among students.

However, incorporating m-learning is not an easy task due to factors involved in applying technology within the teaching process. Yvonne Lam indicates how technological factors might be a burden for some L2 instructors. These factors include the lack of preparation and confidence of some teachers towards technology, the lack of equipment of many schools and language institutions, the limited Internet connectivity and the teachers' illiteracy of technological skills. ${ }^{5}$ Along these same lines, Litchfield et al. ${ }^{6}$ state that $\mathrm{m}$-learning is still in its first stage of development since most uses of m-learning are linked to small tasks in the classroom or fieldwork that involve no complex knowledge; as a result, m-learning tends to be applied accidentally

5 Yvonne Lam, “Technophilia vs. Technophobia: A Preliminary Look at Why Second-Language Teachers Do or Do Not Use Technology in Their Classrooms," Canadian Modern Language Review 56, 3 (2000): 389-420 (390). DOI: https://doi.org/10.3138/cmlr.56.3.389.

6 Andrew Litchfield, Laurel Dyson, Elaine Lawrence and Agnieszka Zmijewska, "Directions for MLearning Research to Enhance Active Learning," Proceedings ascilite, Singapore (2007) 587-596. 
in the classroom. In other words, it is not part of the curriculum, but rather a recurrent teaching tool that a teacher may rely on to assist learning. ${ }^{7}$ Therefore, when educational institutions must invest in a new set of high cost, cutting-edge technologies, educators struggle to decide which new software or devices are beneficial and suitable for their courses. This uncertainty causes teachers to hesitate when implementing m-learning.

With such caveats in mind, the authors of this paper acknowledge the need to investigate how $\mathrm{m}$-learning is being used in their instructional setting. Here, the researchers address this issue based on initiatives taken in other countries and analyze how m-learning is similar or different within the EFL teaching environment in their own institution. Because m-learning is still novel for many, some EFL instructors may not be prepared to deal with the implementation of phones or tablets as methodological tools in the classroom. This premise is supported by Lam, who asserts that there is a gap between EFL instruction and new technological classroom instruction. ${ }^{8}$ The purpose of the present study is to appraise how m-learning is currently implemented and to suggest the need for a platform for introducing new methodological strategies based on m-learning at the Escuela de Literatura $y$ Ciencias del Lenguaje (ELCL) of the Universidad Nacional (Costa Rica). ${ }^{9}$

As discussed below, current studies on m-learning associate successful language instruction with fulfilling students' needs and interests. However, these studies have yet to identify the most effective approaches for m-learning for the current generation. In addition, they do not focus on the training required for this purpose. Therefore, the present study explores how complementary training on m-learning within an integrative mobile approach may make teaching and learning more effective, and thus have a positive effect on students' language proficiency by improving the learning process inside and outside the classroom. This integrative

7 Lam, 3.

8 Lam, 4

9 Escuela de Literatura y Ciencias del Lenguaje [School of Literature and Language Sciences]. 
approach leads to the proposal of training instructors to enhance their teaching by using m-learning approaches without altering or modifying the established methodology and course contents.

\section{Literature Review}

Diverse studies have inquired into the use of technology and how this trend has inevitably changed people's daily lives. In fact, its use influences higher levels of excellence in different fields, including education directly and modifying curriculum and methodology. For Litchfield et al., ${ }^{10} \mathrm{~m}$-learning facilitates learning and access to educational materials. Likewise, Crompton ${ }^{11}$ defines mobile learning as involving multiple contexts and taking place through social and content interactions using personal electronic devices. These studies suggest that m-learning aids the learner with the mobility and portability of handheld devices as tools to support the learning process. M-learning is a subdivision of the E-learning movement (known as computer-assisted language learning-CALL) that emerged in the early 1990s as a response to the rapid digital technology advances such as smartphones, tablets or computers used in education. ${ }^{12}$ For Ally and Prieto-Blázquez, "wireless mobile devices are small enough to be portable, [allowing] learners to use them anywhere and anytime to interact with other learners everywhere to share information and expertise, complete a task or work collaboratively on a project." ${ }^{13}$ They provide a good example of how technology impacts higher education where students are more independent in their learning process. It

10 Litchfield et al.

11 Helen Crompton, "A Historical Overview of Mobile Learning: Toward Learner-Centered Education," Handbook of Mobile Learning (New York: Routledge, 2013).

12 Jack Burston, "Realizing the Potential of Mobile Phone Technology for Language Learning," IALLT Journal of Language Learning Technologies 41, 2 (2011): 56-71 (58). DOI: https://doi. org/10.17161/iallt.v41i2.8490.

13 Mohamed Ally and Josep Prieto-Blázquez, "What is the Future of Mobile Learning in Education?," International Journal of Educational Technology in Higher Education 11, 1 (2014): 142151 (144). 
easier to carry a smartphone than an encyclopedia or spend hours at the library, when it is possible to get the same results almost instantly. Mobile learning is a ubiquitous resource of foreign language teaching in higher education. Likewise, Akour states that guiding a dynamic classroom setting is intrinsically linked to students' learning needs and preferences. ${ }^{14}$ Thus, more educational systems are implementing mobile learning approaches which, as Saliba mentioned, consist of the use of E-platforms to practice, study or internalize classroom subjects. ${ }^{15}$ Al-Emran and Shaalan ${ }^{16}$ point to the global spread of m-learning in educational systems, and to the similarity of the difficulties faced by educators and students. They found that educators' use of m-learning was highly motivated by three major components: academic rank, experience, and geography. One of the conclusions drawn from their study is that the adaptation and evolution of E-learning is developing in a natural but disorganized fashion. Similar to Al-Emaran and Shaalan, Greig Krull and Josep M. Duart ${ }^{17}$ state that the more m-learning is used, the wider the scope of settings. Implementing m-learning in curricula has been a challenge in most educational and second language learning environments. The studies discussed below illustrate the impact that m-learning has had on higher education in certain countries.

14 Hassan Akour, "Determinants of Mobile Learning Acceptance: An Empirical Investigation in Higher Education," ProQuest LLC Dissertations (2010).

15 Gina Saliba, Lynnae Rankine and Hermy Cortez, Fundamentals of Blended Learning (Penrith: University of Western Sydney, 2013).

16 Mostafa Al-Emram and Khaled Shaalan, "Learners and Educators' Attitudes towards Mobile Learning in Higher Education: State of the Art," International Conference on Advances in Computing, Communications and Informatics (ICACCI), (2015): 907-913 (907). DOI: https://doi.org/10.1109/ icacci.2015.7275726

17 Greig Krull and Joseph M. Duart, "Research Trends in Mobile Learning in Higher Education: A Systematic Review of Articles (2011-2015)," International Review of Research in Open and Distributed Learning 18, 7 (2017). DOI: https://doi.org/10.19173/irrodl.v18i7.2893 


\section{The Use of M-learning in Higher Education}

El-Hussein and Cronje claim that "mobile learning as an educational activity makes sense only when the technology in use is fully mobile and when the users of the technology are also mobile while they learn..$^{18}$ In other words, the learner at the center of instruction may move as necessary, hence allowing the learning process to take place in any context and situation. Accordingly, the main characteristic of handheld mobile devices is its ubiquity which allows learners to access information and communicate efficiently in real time for educational purposes both inside and outside learning settings. Actions in m-learning/teaching started to develop in the 1990s with the Internet and mobile technologies, and more recently, m-learning has grown globally in higher education, exemplifying the use of m-learning within the classroom in language learning and in other fields of study. First, some higher education studies regarding m-learning will be addressed with relation to the thesis of the present study. Second, some equivalent studies launched by Ministries of Education in Latin America with the joint efforts of nongovernmental organizations will be described. Those included below are merely a sample of many others conducted all over the world.

\section{Thailand}

Jairak et al. carried out a study to appraise the main ways in which students use mobile devices for learning purposes. This study adopted two framework models: the Unified Theory of Acceptance and the Use of Technology to quantity the factors that influence the college students' level of acceptance of m-learning. To this end, 390 students from five private and public universities were surveyed to inquire about performance and effort expectancy, attitudes and behavior in class and other such as social factors, and educational facilitating

18 Mohamed Osman, M. El-Hussein and Johannes C. Cronje, "Defining Mobile Learning in the Higher Education Landscape," Educational Technology and Society 13, 3 (2010): 12-21 (14). 
conditions. The results revealed a surprisingly high level of usage and acceptance of mobiles to assist college students learning among higher education learners in this country. ${ }^{19}$

Another study carried out by Paul T. J. James (2011), ${ }^{20}$ showed how relevant $\mathrm{m}$-learning has become within higher education. This research targeted $4^{\text {th }}$-year undergraduate students in a business major. He chose this level bearing in mind that the students already had a clear notion of how to work with some technological tools as this was their last year. He chose a focus group of 15 students randomly from a total 256. His findings provided enough information to conclude that students' perceptions about m-learning were not definitive. Though students' responses displayed their knowledge about m-learning, they also provided evidence of deficiencies in the use of m-learning in higher education course curricula.

Both studies showed a clear position of the role of mobile devices and the acceptance of the higher education students toward incorporating m-learning whether explicitly or not, indicating its presence in the students' ongoing activities and educational development.

\section{Australia}

The project "Teaching Teachers for the Future" was run in Australia during 2011-2012 to train pre-service higher education teachers around the country to use information and communication technologies resourcefully and build technological capabilities for the future. This project was financed by the Schools Division of the National Department of Education and the Department of Education, Employment and Workplace Relations addressed to the higher education sector. This governmental action aimed to change

19 Kallaya Jairak, Prasong Praneetpolgrang and Kittima Mekhabunchakij, "An Acceptance of Mobile Learning for Higher Education Students in Thailand," International Journal of the Computer, The Internet and Management 17, SP3 (2019): 36.1-36.8.

20 Paul T. J. James, "Mobile-Learning: Thai HE Student Perceptions and Potential Technology Impacts," International Education Studies 4 (2011): 182-194 (182). DOI: https://doi.org/10.5539/ies. v4n2p182. 
the national curriculum and educational pedagogy to fulfill the digital requirements of the $21^{\text {st }}$ century. This project did not quantify the results or the impact on teachers' training and performance. ${ }^{21}$

Likewise, a "Student Mobile Survey" conducted in Australia, a pioneer in m-learning research by the University of Technology Sydney (UTS), revealed that $95 \%$ of the subjects regularly use mobiles for study purposes and $72 \%$ expressed a willingness to incorporate $\mathrm{m}$-learning into the classroom. This survey was conducted online by Litchfield et al. with 442 students between February and March 2007. Most of the students were Information Technology (IT) students. The results helped UTS to carry out m-learning trials that year, which provided the researchers with a variety of types of digital input on how students handle technology within the educational system. On the other hand, it also exposed their weaknesses using technological features. These discoveries enabled UTS to implement a friendlier and more digitalized curriculum for students and teachers. ${ }^{22}$

Although the results of the two studies were not conclusive for major educational changes, they did help the authorities to modify how m-learning could be incorporated into classroom methodology.

\section{China and Sweden}

Olga Viberg and Âke Grönlund measured the attitudes toward mobile devices of foreign and second language learners to determine the extent to which cultural background and/or differences influence the way language is acquired. For this purpose, 345 learners from both Dalarna University in Sweden and Yunnan University in China were surveyed. The purpose was to learn how technology was perceived and used in such different cultures and countries within higher education students. This case study presented participants' attitude towards technology according to their cultural background and individual desire to learn. Their findings show that the respondents' attitudes toward

21 Jairak et al.

22 Litchfield et al. 
mobile learning are very positive with individualization being most positive $(83 \%)$, followed by collaboration $(74 \%)$, and authenticity (73\%). These results suggest that cross-culturalism does not play an important role when learning languages; however, handheld mobile devices impact and enhance learning positively. ${ }^{23}$

The relevance of this study regarding $\mathrm{m}$-learning is that some new generations of students may be more reluctant towards the use of technology in the learning process; however, a more restricted environment such as that ofChina seemed to handlem-learning quite well.

Iran

Mohammadi conducted a similar investigation titled "Social and individual antecedents of m-learning adoption in Iran." This exploratory study measured the usage, intention and satisfaction of $\mathrm{m}$-learning in Tehran. The data was collected at four public universities and a total of 390 students were interviewed. The instrument covered the following main factors: subjective norm, intention, ease of use, and individual mobility. The most noteworthy finding in the study is that the subjective norm is a major factor that affects students' use and functionality of mobile devices. The results showed that although the Iranians in this study demonstrated a positive tendency towards the use of m-learning, the need to implement a cooperative approach to promote involvement, and active interaction among students is clear. ${ }^{24}$ Although culturally Iranians prefer face-to-face speaking encounters in higher educational settings, communication via electronical devices has a very outstanding place among subjects interviewed.

23 Olga Viberg and Âke Grönlund, "Cross-Cultural Analysis of Users' Attitudes toward the Use of Mobile Devices in Second and Foreign Language Learner in Higher Education: A Case from Sweden and China," Computers \& Education 69 (2013): 169-180. DOI: https://doi.org/10.1016/j. compedu.2013.07.014.

24 Hossein Mohammadi, "Social and Individual Antecedents of M-learning Adoption in Iran," Computers in Human Behavior 49 (2015): 191-207. DOI: https://doi.org/10.1016/j.chb.2015.03.006. 


\section{M-learning in Latin America}

M-learning projects conducted in Latin America are described in an attempt to get a broader perspective of how technology is spreading rapidly among teaching learning environments. For example, the nonprofit organization UNESCO (United Nations Educational, Scientific and Cultural Organization) has promoted the concept of technology in the field of education keeping as premises these basic elements: education is a human right, and it has to move along with the world progression. Even though UNESCO recognizes that technology is not the panacea to education, it does stress that its usage can contribute and impact people's learning in ways that would not be reachable decades ago. According to UNESCO officials, the impact of $\mathrm{m}$-learning goes beyond havong a smartphone. Used properly, it can reach the most marginalized and neglected populations. In a world that by 2012 had reached 5.9 million phone plan subscriptions, the idea of providing education via m-learning seems to be more suitable and feasible..$^{25}$

María Teresa Lugo and Sebastián Schurmann, UNESCO collaborators carried out a study to outline the initiatives of m-learning in Latin America. The most noteworthy areas were primary and secondary education. To select the initiatives where m-learning is being applied, relevant issues were taken into consideration such as the educational system, the number of graduated students, social and economic status. The first initiative was Raising Literacy Rates from Colombia where the Colombia's Minister of Education joined by the Ministry of ICT and the Organization of Ibero-American States (OEI) created the national program to alphabetize some 1.7 million people nationwide ${ }^{26}$ Known as the National Literacy Program, the government planned to provide mobile devices to literate underprivileged areas of the country. Each device had a SIM card that contained six modules

25 Mark West, Turning on Mobile Learning. Global Themes (Paris: UNESCO, 2012) 6.

26 María Teresa Lugo and Sebastián Schurmann, Turning on Mobile Learning in Latin America (Paris: UNESCO, 2012) 19. 
of interactive and self-directed educational material with the purpose of stimulating the knowledge of the participants.

Unlike the initiative in Colombia, the PSU Mobile in Chile was oriented mainly toward providing access for users to higher education. PSU mobile was an initiative to help low-income students to practice before applying the test to enter into university. The Minister of Education in Chile together with the Chile Foundation created an app called PSU mobile that helped candidates to do exercises, listen to podcasts, and take practical exams thus serving as platform to prepare low socioeconomic students to pass university admission exams. The last count of users who visited the application was 4.4 million individuals, a number that appears to grow every day. ${ }^{27}$

They also mention Improving Teaching and Learning: BridgeIT and Seeds of Empowerment, two initiatives dealing with m-learning but in various countries simultaneously. ${ }^{28}$ BridgeIT is a global project directed by Nokia, the Pearson Foundation, the United Nations Development Programme (UNDP) and the International Youth Foundation (IYF). Its main objective is to concentrate efforts on helping teachers improve during their educational career to have an impact on classroom methodology by applying what they learned in the program. Each participant was given a smartphone to access the database called NED (Nokia Education Delivery). In this database, teachers have access to materials, exercises and a planning kit prepared by other participants involved. BridgeIT also reached out to students by creating an m-learning program called Building Bridges to enable students to improve in Math, English and Science by exposing them to material, videos and additional practice. Similar to BridgeIT for students, Seeds of Empowerment aims to spread the improvement of Math in schools. The first Seeds of Empowerment projects in Latin America were launched in 2008 in schools in Argentina, Mexico and El Salvador, and other projects are anticipated in Bolivia, Brazil and

27 Lugo and Schurmann, 20.

28 Lugo and Schurmann, 22. 
Uruguay in $2012 .{ }^{29}$ There are many more initiatives that UNESCO and other partners have done around the world regarding the implementation of m-learning in education.

Costa Rica

Different from the above, no systematic study has been found on the use of m-learning in higher education in Costa Rica, or on the teaching of a second language. Although it is well-known that portable electronic devices such as smartphones, tablets or computers are for personal use, it is also understood that they are being used as educational tools at the university level, but not systematically. Already in 2005 Alvarado Martínez discusses how the UNA has been using Moodle, a platform for Aula Virtual (Virtual Classroom), whose objective is to use the web as a means of a continuous learning process. ${ }^{30}$ With this platform, professors can keep in touch with students by using blogs, emailing homework, and holding virtual classroom discussions or video-conferences. Initially, this platform was used inflexibly because students had to be at home using the computers or at a library. Nonetheless, new technology brought the era of smartphones, allowing users to be connected continually. Therefore, the creation of smartphone apps has moved the learning process into a somewhat random m-learning experience. Professors and students use apps to facilitate the teaching or learning process, but how systematically these apps are used as a methodology is uncertain. Internet accessibility has led educational systems into a more dynamic teaching process and promotes methodological techniques to adjust to the new area of learning and knowledge acquisition.

29 Lugo and Schurmann, 23.

30 Guisselle Alvarado Martínez, "As TIC, geradoras da nova cultura informática: uso da "Aula Virtual," Universidad Nacional, Costa Rica," Semina: Ciências Sociais e Humanas 37, 1 (2016): 119-127 (122). DOI: https://doi.org/10.5433/1679-0383.2016v37n1p119. 


\section{Overall Implications}

Though not all of the above projects were explicit about both learning a second language and the use of m-learning, it is evident that $\mathrm{m}$-learning is a key player and its role is worthy of further attention in the process of foreign/second learning and teaching.

\section{Theoretical and Practical Gaps}

As discussed above, the foremost research within m-learning carried out in higher education is mainly descriptive and represents the students' point of view (see Paul T. J. James, in Thailand; or Mohammadi, in $\operatorname{Iran}^{31}$ ). These studies provide merely one perspective where m-learning is applicable, a circumstantial position in terms of usage in the educational context: teachers, students and curricula. Relatively less work has focused on training teachers on how to implement mobile devices in their classes, and the results are rarely reported. Not only do these investigations fail to come to an agreement on the most effective approach to use m-learning, but they often do not fulfill the expectations of millennium generation learners. This is not surprising given that the field of m-learning is in continuous change and expansion due to the rapid appearance of new portable devices. A good example of this is presented by UNESCO, which has opened a section on m-learning for teachers to provide online support and training to a world with around six billion cell phone subscribers worldwide.

\section{Frameworks for Integrating M-learning}

As handheld devices continue to evolve, so does their tendency to be used in education. Thus, several models for integrating mobiles and enhancing learning have been developed. Four existing m-learning models used in higher education are described here. One of these models is called FRAME, which stands for "Framework for the Rational Analysis of Mobile Education." This model is currently being implemented in the Athabasca University in Canada. According to

31 James, 2. 
Marguerite Koole, this model "takes into consideration the technical characteristics of mobile devices as well as social and personal aspects of learning. ${ }^{32}$ "'The model incorporates three main pillars when planning and designing classroom activities by providing meaningful opportunities to acquire, exchange, and practice information through significant mobile learning experiences. Additionally, this model provides a checklist for instructors to measure the level of engagement of learners when using mobile devices.

Mobling, developed by Gary Mielo, ${ }^{33}$ is another well-known model. This framework aims to maximize learning with online visual aids such as pictures and texts. It consists of creating posters to present new information as well as murals or animated notetaking pads to recall information or develop online visual projects to investigate or internalize information. This model was created to facilitate learning and instruction by means of simulating the construction of diaries or scrapbooks.

Moreover, the SAMR framework is based on four main dimensions: substitution, augmentation, modification, and redefinition, and each contributes to supporting and transforming students' learning through technology. Romrell and Wood state that "transformational learning activities that are truly personalized, situated, and connected through the use of a mobile device will go beyond merely using a mobile device as a substitute for more traditional tools." ${ }^{34}$ Hence, the first level, substitution refers to the integration of any available technological tool within a task. Augmentation deals with the implementation of technological tools in the classroom to develop a meaningful task that goes hand in hand with the added functionalities of the technological devices available. Modification is the level

32 Marguerite Koole, “A Model for Framing Mobile Learning," Mobile Learning: Transforming the Delivery of Education and Training (Canada: Athabasca University Press, 2009) 26.

33 Gary Mielo, "The Medium is the Moblog," ETC: A Review of General Semantics 62, 1 (2005): 28-35.

34 Danae Romrell, Lisa C. Kidder and Emma Wood, "The SAMR Model as a Framework for Evaluating mLearning." Online Learning (formerly: Journal of Asynchronous Learning Networks) 18, 2 (2014): 82-97. 
where the task is accomplished by adapting the functionalities of the technological devices or modifying the task itself to integrate technology. Finally, redefinition corresponds to the evaluation of the task or the design of a new task taking into account recently acquired knowledge. This model is widely used for either designing classroom tasks or evaluating the outcomes of the tasks. ${ }^{35}$

The last model is a teaching project developed by Burston, called MobLang (mobile language learning), which seeks to "provide majority language speakers with basic communicative competence in languages that have minority status in their country." ${ }^{" 36}$ The project was made up of a series of lessons to teach L2 learners basic formulaic expressions in the target languages using a mobile phone platform. The project proved to be successful in communicating basic language functions in the target languages.

Even though various models are used nowadays for mobiletool-based teaching, this paper does not favor any particular one but rather the integration of the best practices and artifacts described in those models. Thus, this investigation aims to shed some light on possible directions for improving traditional teaching without altering the established curriculum. In the light of this objective, a series of research questions should be formulated as a guide, and collect the information needed not only to discern how m-learning is used by the professors teaching in the ELCL English, but also to provide input for the eventual design of a model to serve as a guidance for integrating m-learning systematically.

\section{Research Questions and Methodology}

The methodology used in the present study corresponds to that required to address the following research questions:

35 Romrell and Wood, 82.

36 Jack Burston, "Mobile Language Learning: Getting IT to Work." Foreign Language Instructional Technology: Theory and Practice (Chipre: University of Nicosia Press, 2012) 82. 
1. How is m-learning integrated in the classroom by UNAELCL professors?

2. What types of mobile devices are used to teach language skills in the ELCL?

3. In what learning and teaching contexts is m-learning often implemented at the ELCL?

\section{Methodology}

This study used an exploratory qualitative and descriptive design. It starts with a perceived notion of how m-learning might be used in the Bachelor's in the Teaching of English as a Foreign Language (BEI), ${ }^{37}$ followed by set of questions to guide the data collection process and analysis. For this purpose, the researchers developed a questionnaire on how m-learning is viewed, applied and exploited in the program.

The BEI is divided into four years to reach the bachelor's degree. The first year, students take one integrated course taught by two instructors where all language skills are combined, and the methodological courses are given the School of Education. The second year the skills are split into areas such as grammar, writing, speaking, reading and listening. The third and fourth year courses are distributed similarly to those of the second one; however, some courses become more specialized, and an additional literature course, as well as the mandatory general studies courses established by the university. That comes to a total of 144 credits. $^{38}$

The UNA has offered bachelor's degrees in English since 1975. They have been modified many times, adapting to new methodologies and teaching approaches. In the last decade, this university major has reached its third round as an accredited program. This leads, therefore, to the need to fill gaps found by evaluators especially regarding technology and its implementation in the classroom. Thus, the aim of the present research is to inquire about how familiar UNA-ELCL

37 Bachillerato en la Enseñanza del Inglés.

38 Alejandra Giangiulio, academic coordinator of the English department, ELCL, UNA (2018). 
professors who work at BEI are regarding the use of m-learning. Finally, an integrative approach can be suggested as a way to increase students' engagement and learning in the language classroom.

To collect the data required, 22 instructors working in this program were chosen to complete a questionnaire. Although 44 faculty members belong to in the English department, ${ }^{39}$ only half were selected because they were actively teaching in this program at the moment when the instrument was distributed. The subjects' ages range from 25 to 55. Most of the professors have taught a variety of courses and at the different levels in the program. They were asked to complete the questionnaire based on their experience and methodology as well as on their knowledge of e-techniques.

\section{Instrument: The Questionnaire}

The instrument used to appraise the teachers' usage of m-learning in their classes was a group-administered questionnaire (see appendix 1). The questions were selected according to the queries established in the research questions of this study. In total, this instrument contained seven questions and it was divided into two parts. The first two questions are closed in type: the first, about the frequency with which mobile devices are used to aid the learning process, and the second, with a list from which teachers selected how mobile devices are used to learn English as a foreign language. Additionally, questions 3 to 7 are open-opinionated inquiries about the type of apps used to assist learning, benefits and drawbacks obtained through the use of mobile devices, teaching approaches followed when implementing m-learning, and the type of instruction received to apply m-learning effectively in the classroom. The questionnaire was administered over a period of one month during faculty meetings.

To validate the questionnaire, three professors from the sample group were asked to evaluate the validity of the items and their

39 Giangiulio. 
sequence. This contributed to getting consistent and accurate results. The main purpose of this instrument was to quantify the number of instructors whose methodological strategies involved m-learning techniques. Once the information was gathered, it was analyzed and interpreted to establish the usage of m-learning in ELCL as well as to make a series of suggestions for implementing a teaching proposal by which all instructors might exploit m-learning strategies as support during class.

The population was chosen based on the colleagues who were currently working with the BEI program. During a department meeting, the researchers explained the purpose of the study and requested the subjects to complete the questionnaire. To analyze the data, the researchers established a schedule to start working on gathering the information yielded by the instrument. Time was taken to quantify the data. Each of the researchers first worked separately scrutinizing the responses, and then met to compare the numerical results, thus controlling subjectivity and preventing discrepancies in the results. Once the data was gathered systematically, an overall analysis was carried out taking into consideration the premises of the investigation as presented in the research questions.

\section{Data Analysis}

The data collected from the questionnaire included the responses of all 22 participants. The data collected and displayed in the graphs represent $88 \%$ of the total number of the faculty members who taught EFL courses during the second semester in 2017. The data from the analysis of the questionnaires is paralleled with the results of previous studies. With this intention, the results are presented in the form of graphs, tables and numbers, and the conclusions drawn may serve as insights. Eventually these insights will nurture the proposal of an integrated m-learning approach at the BEI program at ELCL. 
Regarding question 1, on the frequency of usage of mobile devices to aid students in their learning process, $4.3 \%$ of the professors queried indicated they always use them, and $9 \%$ indicated that they use mobiles most of the time; $54.5 \%$ reported using them sometimes and $31.8 \%$ rarely. Thus, graph 1 suggests that instructors have space to increase the use of mobile devices in their daily teaching.

Graph 1. Use of mobile devices to aid students in their learning process

\section{Frequency of Use of Mobile Devices}

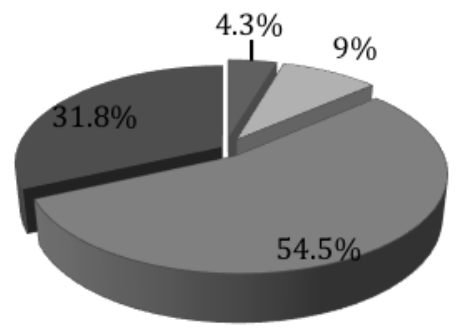

always

most of the time

sometimes

rarely

Question 2 refers to whether the professors consider mobile devices useful in classes related to the learning of English as a foreign language. For this purpose, the following list of fourteen common ways of using mobile devices was provided: using E-dictionaries, playing music/videos/podcasts, taking photos, using E-books, posting photos/ images online, playing educational games, using a clock/alarm/timer, using a social network, downloading apps, scanning QR codes, using education apps, sending/receiving text/email messages, recording videos/audios and creating apps/QR codes. Graph 2 exemplifies the six most common ways in which instructors currently find mobile phones useful in class. For example, $95 \%$ of the professors agreed that smartphones are used to consult E-dictionaries while $77.2 \%$ of the interviewees indicated having used mobiles for sending or receiving text or email messages, and recording videos or audios, a tool more for a personal purposes and as a means of communication. 
Being this a question with a number of choices, it was found that $63.3 \%$ of the instructors used mobiles for playing music, videos or podcasts. Also, $54.5 \%$ pointed out that cellphones are mostly needed to set the alarm clock and keep track of the time, while $59.9 \%$ of the professors confirmed that they use them to check their social network profiles. Graph 2 shows these six common ways which were singled out as the most significant ones in terms of their phone's usability.

Graph 2. Ways of using mobile devices

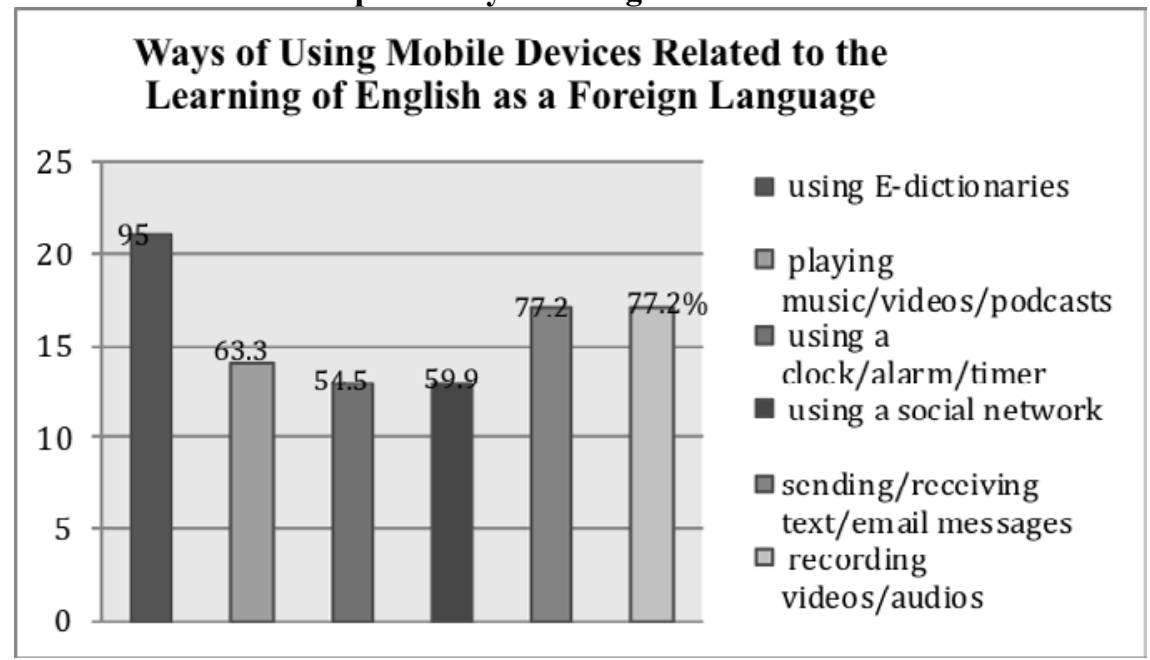

As to which apps are commonly used inside or outside the classroom to assist students' learning in the BEI courses, graph 3 displays the answers to question 3, for which 54.5\% reported using E-dictionaries; $31.8 \%$, social network apps; $13.6 \%$, pronunciation apps; $13.6 \%$, educational sites; and $22.7 \%$, voice recorder apps. On the other hand, only one participant (4.3\%) reported regularly using apps such as Kahoot, word reference sites, QR readers, book readers, podcasts, email, translation tools, and virtual classes. One instructor reported not using any app at all, and only one reported having used the virtual classroom available since 2005 as an academic resource. 
Graph 3. Apps habitually used inside or outside the classroom to assist students' learning

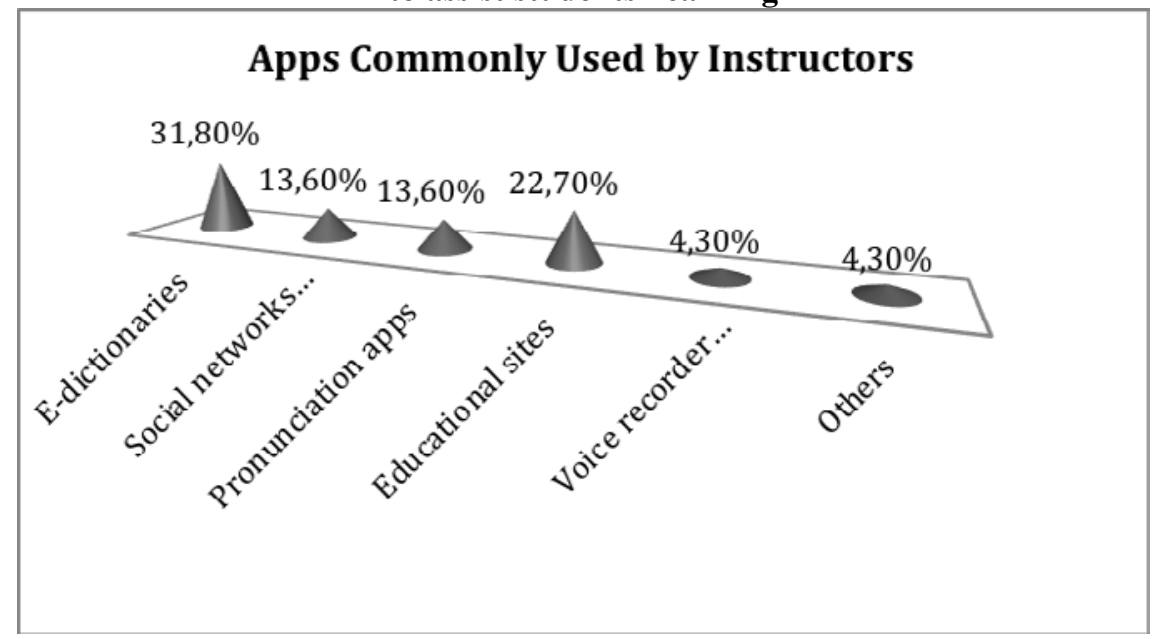

Along these same lines, questions 4 and 5 referred to the benefits and the drawbacks of using mobile devices in the language classroom. The professors identified these strengths: getting students engaged in the class activities, having students actively interact and participate in class, including students' interests, accessing information in real time, and permitting constant communication among students and teachers in and outside of class. The last compelling advantage for using mobile devices is to practice and improve students' language skills. In contrast, some of the drawbacks teachers commonly cope with while using mobiles in class are that the Internet connection tends to fail, or is very slow on the campus, that students frequently face many online media distractions and/or lose concentration, that some students do not own a smartphone or have one in a pre-paid plan, which limits Internet usage, and that some good apps require users to pay or may not be compatible with the students' portable device.

Question 6 inquired into the teaching methods that instructors prefer when implementing m-learning in the classroom. On the one 
hand, the results showed consensus among thirteen of the participants who stated that they apply the following methods for teaching using mobile devices: constructivist, task-based, cognitive and communicative approaches. All in all, through their comments they make it clear that they use mobile devices as a complementary resource. On the other hand, eight of the interviewees bluntly stated that they do not follow any particular approach either to implement technological tools or to integrate the use of mobile devices in their classes, but they fortuitously use cellphones when the lesson or topic demands it. One had used the CALT-CALL approach when implementing the use of mobile devices in class.

In the same vein, question 7 inquired about whether instructors had received instruction in applying $\mathrm{m}$-learning in the classroom. Only $22.7 \%$ reported having received specific training on how to implement the use of mobile devices in their class, while $77.2 \%$ reported not having received any formal training on the matter.

\section{Summary of Results}

Overall, the results of this investigation showed some level of unwillingness towards incorporating and adapting $\mathrm{m}$-learning practices. The data analysis may suggest that $\mathrm{m}$-learning goes beyond having an electronic device and using it in class as a complementary tool to deal with in situ cases; nonetheless, its usage should involve some planning, a model design, and a teaching strategy. However, the findings are not conclusive, and more research is required especially to appraise the students' perceptions and opinions. This research is a first step toward estimating the degree to which m-learning is incorporated by BEI professors and proposing the implementation of an integrative mobile approach to aid the teaching and learning processes at UNA language courses.

Tables 1 and 2 summarize the findings of the data collected from open and closed-ended questions in the questionnaire. Table 1 
provides a summary of the results of the closed-ended questions 1 and 2 , and the open-ended questions 3 and 7 from the questionnaire.

Table 1. Frequency, usefulness of mobile devices, most common apps used and instruction received to aid students in their learning process

\begin{tabular}{|l|l|l|l|}
\hline \multicolumn{1}{|c|}{ Item/questions } & Main result 1 & Main result 2 & Main result 3 \\
\hline $\begin{array}{l}\text { Question 1 } \\
\text { Frequency of usage of } \\
\text { mobile devices }\end{array}$ & $\begin{array}{l}4.3 \% \\
\text { always }\end{array}$ & $\begin{array}{l}54.5 \% \\
\text { sometimes }\end{array}$ & $\begin{array}{l}31.8 \% \\
\text { rarely }\end{array}$ \\
\hline $\begin{array}{l}\text { Question 2 } \\
\text { Usefulness of mobile } \\
\text { devices in the class }\end{array}$ & $\begin{array}{l}95 \% \\
\text { looking up } \\
\text { words in } \\
\text { E-dictionaries }\end{array}$ & $\begin{array}{l}77.2 \% \\
\text { sending and } \\
\text { receiving text or } \\
\text { email messages }\end{array}$ & $\begin{array}{l}\text { f3.3\% } \\
\text { playing music, } \\
\text { videos or } \\
\text { podcasts }\end{array}$ \\
\hline $\begin{array}{l}\text { Question 3 } \\
\text { Most common apps } \\
\text { used to assist students, } \\
\text { learning }\end{array}$ & $\begin{array}{l}54.4 \% \\
\text { e-dictionaries } \\
\text { apps }\end{array}$ & $\begin{array}{l}\text { 31.8\% } \\
\text { social network } \\
\text { apps }\end{array}$ & $\begin{array}{l}13.6 \% \\
\text { pronunciation } \\
\text { apps }\end{array}$ \\
\hline $\begin{array}{l}\text { Question 7 } \\
\text { Training received to } \\
\text { apply m-learning in the } \\
\text { class }\end{array}$ & $\begin{array}{l}22.7 \% \\
\text { yes }\end{array}$ & $\begin{array}{l}77.2 \% \\
\text { no }\end{array}$ & \\
\hline
\end{tabular}

Table 2 provides a summary of the results of open-ended questions 4-6. 
Table 2. Benefits, drawbacks and teaching approaches

\begin{tabular}{|c|c|}
\hline $\begin{array}{l}\text { Question } 4 \\
\text { Main reported benefits of } \\
\text { using mobile devices to } \\
\text { assist students' learning }\end{array}$ & $\begin{array}{l}\text { 1. Get students engaged in the class activities. } \\
\text { 2. Have students actively interact and participate } \\
\text { in class. } \\
\text { 3. Include students' interest. } \\
\text { 4. Access information in real time. } \\
\text { 5. Keep constant communication among students } \\
\text { and professors. } \\
\text { 6. Practice and improve students' language skills. }\end{array}$ \\
\hline $\begin{array}{l}\quad \text { Question 5 } \\
\text { Main drawbacks faced } \\
\text { when using mobile } \\
\text { devices to assist students' } \\
\text { learning }\end{array}$ & $\begin{array}{ll}\text { 1. } & \text { Failure of Internet connection } \\
\text { 2. } & \text { Low speed of Internet connection } \\
\text { 3. } & \text { Online media distractors } \\
\text { 4. } & \text { Limited Internet usage } \\
\text { 5. } & \text { Payment required to use certain useful apps } \\
\end{array}$ \\
\hline $\begin{array}{l}\text { Question 6 } \\
\text { Teaching approaches } \\
\text { followed by professors } \\
\text { when implementing } \\
\text { m-learning }\end{array}$ & $\begin{array}{ll}\text { 1. } & \text { Constructivist approach } \\
\text { 2. } & \text { Task-based approach } \\
\text { 3. } & \text { Cognitive approach } \\
\text { 4. } & \text { Communicative approach } \\
\text { 5. } & \text { CALT-CALL approach }\end{array}$ \\
\hline
\end{tabular}

In general, it can be seen above that although many may agree on promoting learners' linguistic proficiency by using technological devices, they still fail to provide a model or scheme for L2 learners. The data collected in the present study could serve as initial input for the development of the proposal and operationalization of a systematic plan to accomplish this goal. The pedagogical implications drawn from this research, in terms of the planning required to make use of mobile devices, provide insightful suggestions for effective learning. In consequence, this initial input together with further research and experimentation could potentially lead to the development of the proposed approach to be implemented in this major and feasibly replicated in other contextually similar EFL programs and courses. 


\section{Discussion and Conclusions}

M-learning is an emerging field widely studied by language scholars to adapt new technologies and electronic devices to enhance their teaching and classroom dynamics. The results, therefore, show the appraisal of BEI professors towards the use of m-learning and provide pertinent insights that serve the main objective proposed in this paper to design an integrative model to be used by teachers and students from ELCL as a methodological learning-teaching aid. Succinctly, the following main conclusions may be drawn.

1. On the question of how m-learning is integrated into the classroom by UNA-ELCL professors, the findings suggest that there is probably no one clear-cut established and integrated methodology on the use of electronic devices by BEI instructors as supplementary teaching tools. The use of m-learning as a methodology appears not to be applied by instructors systematically, and more than a half of them reported not having received any training on the implementation of mobile devices. It suggests that its application has to do with random circumstances rather than a plan designed specifically for the purpose of integrating m-learning into the course.

2. On the types of mobile devices used to teach language skills in the ELCL, the use of smartphones, tablets and other mobile devices, it has become clear that these devices are just tools to support the teaching process and promote learning, as occurs with any other methodological approach. As stated in the data analysis, around more than three quarters of the BEI instructors reported to use mobile devices sometimes and/or rarely during class periods. Therefore, it is inferred that m-learning does not provide direct instruction habitually from teachers to students. Although determining whether m-learning is used as a methodological technique was not the objective of the study, the responses provided by the subjects indicate that m-learning usage is primarily instrumental. 
3. Regarding the learning and teaching contexts wherem-learning is often implemented at the ELCL, the results of this study suggest that since BEI professors commonly use mobile apparatuses as consulting tools for checking spelling, clearing up concepts, revising pronunciation references, sending and receiving text/email messages, and checking social networks, those uses do not necessarily reflect detailed planning processes for the systematic inclusion of m-learning. The fine line between using technology to improve the students' performance and using it for better teaching and learning points to the need for a straightforward objective when using technology in a language classroom.

Moreover, the following minor findings in this study, based on the comments made by BEI professors at the end of the questionnaire, coincide with results from many of the previous studies cited in the literature review:

1. The portability and ubiquity of personal mobile devices facilitates students' usage and accessibility in the language classroom.

2. The use of mobile devices in the classroom supports the fulfillment of learner's expectations.

3. Due to the fact that technologies evolve and expand every day, there is an increasing tendency of language instructors who use mobile devices as a supplementary resource.

4. The usage of mobile devices tends to be normal and unplanned in the language classroom.

The findings suggest that noting how foreign language instructors apply m-learning in class can lead to an orderly and strategic usage of this resource. The application of pedagogical mediation for using mobile devices could help to promote independent learning by instructing college students on how to use technology to complement language learning and to measure students' performance more accurately. In 
addition, the apparent generation gap between professors and students can be reduced, and the curriculum updated with the new technological tendencies in the digital world. By developing an integrative model for m-learning in the classroom, instructors could make the curriculum more flexible and dynamic. Lastly, there is significant information in this study to contribute to the current debate on m-learning as a language approach and potentially lead to the design of a proposal for training on this integrative approach.

\section{Limitations and Future Research}

Amajor concern of this study is that it covers only the instructors' perceptions. By evaluating the students' opinions in the future, researchers could obtain valuable information to compare with that of the professors. Due to the nature of the research instrument, it did not, for the most part, yet yield conclusive findings. While the questions were carefully validated, these results are subject to other interpretations due to sample size and type of instrument used to collect the data. Observations and oral interviews should be included in further research. Another limitation, as some participants noted, is the slow Internet connectivity at the ELCL, preventing cellphones from being used successfully in class.

The present study could lead to future research on m-learning, such as on the benefits of using Smartphone apps to learn a second language, or on specific platforms to practice soft language skills such as spelling, grammar, pronunciation and fluency. This study joins other research worldwide regarding $\mathrm{m}$-learning based on the increasing trend of Bring-Your-Own-Device (BYOD) ${ }^{40}$ Mobile phones are extensively explored in applied linguistics, and the BYOD has caused researchers to turn their attention to other similar devices such as tablets, kindles, and portable gaming consoles.

40 Krull and Duart, 1-23. 


\section{Recommendations for Running an M-learning Integrative Mo- bile Approach}

Given that most of those surveyed stated that they do not know how to implement m-learning, further research could aim to orient this process in lessons where an integrative mobile approach can be applied.Action might be taken on integrating m-learning systematically in the ELCL English program. Despite the limited sample used in this study, there are a number of preliminary recommendations for running an m-learning integrative mobile approach.

1. First, it is necessary to compile a list of available software that can be useful in an EFL classroom. Although thousands of smartphone apps have beend developed for educational purposes, not all are appropriate for the English classroom. Since the professors do not have the time to try them all out, it is imperative to analyze which phone apps, on-line software, websites or Internet programs are more appropriate for the school population (and free of charge) and have proven to have positive results in a given setting.

2. Once relevant m-learning techniques have been selected, workshops could be designed and implemented to train teachers how to apply those m-learning interactions within their curriculum. Training should be classified according to the different teaching areas such as those m-learning programs employed for grammar, pronunciation, writing, speaking, and reading.

3. Thus, it is vital discuss how to implement m-learning. Although no m-learning device will replace academic instructors, its practice may enrich classroom dynamics, modernize the traditional classroom, and engage students more actively while enhancing the teacher's coaching performance.

4. M-learning is a current approach that cannot be ignored at any level of the educational system. However, when using m-learning the instructor is responsible for taking into account the subjects, the target populations, students' ages and technological accessibility. 
Applying m-learning through an integrative mobile approach can benefit students' learning process catching their attention and catering to their interests while learning an L2 at any level (beginning, intermediate or advanced). As stated initially, professors tend to use m-learning randomly — rather than systematically — within their classroom. By helping instructors use smartphones more purposefully as a means of learning a language in an EFL setting, the classroom can become more engaging not only for both learners and teachers.

\section{Appendix 1}

\section{M-learning: An Integrative Approach to Increase \\ Students' Engagement and Learning in the Language Classroom}

The purpose of the following survey is to investigate the use of m-learning in the teaching environment of instructors in the Bachelors of English at this university. In general terms, m-learning is the use of mobile devices to aid students in the teaching-learning process.

Instructions: Please answer the following questions, reflecting your opinions as accurately as possible.

1. How often do you use mobile devices to aid students in their learning process?
a. $\square$ always
b. $\square$ usually
c. $\square$ sometimes
d. $\square$ rarely
e. $\square$ never

2. Considering the different ways of using mobile devices related to the learning of English as a foreign language, which of the following do you currently find useful in class? Mark all that apply. 

a. $\square$ using E-dictionaries
b. $\square$ playing music/videos/podcasts
c. $\square$ taking photos
d. $\square$ using E-books
e. $\square$ posting photos/images online
f. $\square$ playing educational games
g. $\square$ using a clock/alarm/timer
h. $\square$ using a social network
i. $\square$ downloading apps
j. $\square$ scanning QR codes
k. $\square$ using educational apps
1. $\square$ sending/receiving text/email messages
m. $\square$ recording videos/audios
n. $\square$ creating apps/QR codes
o. Other(s):

3. What two apps do you often use in/outside class to assist students' learning in your courses?

4. What benefits have you obtained by using mobile devices to aid your students' learning?

5. What drawbacks have you faced when using mobile devices to assist your students' learning?

6. What teaching approach(es) do you follow when implementing m-learning in the classroom?

7. Have you ever received instruction on how to apply m-learning in the classroom?
a- Yes $\square$
b- No $\square$
If so, what type?

8. Do you have any additional comments that you would like to share about your experience implementing m-learning in the classroom?

\section{Thank you so much for sparing a few minutes to respond to this questionnaire.}


